from which the archæologist interprets advance in civilization and the cultural history of the people as a whole.

Excavations are still proceeding on the site in the hope of securing further evidence, which will throw light on certain points still obscure. It would appear to be beyond doubt from the completeness of the funeral furniture, the extensive equipment, domestic and personal, and the unexampled richness and excellence in workmanship of the jewellery and objects in precious metal, that this was the burialplace of a king or chiefly leader, which is to be assigned, on the evidence of the Merovingian coins, though themselves bearing no date, to about A.D. 640 ; but as yet no evidence of identification has been found. Such suggestions as have been made are purely speculative. It is further remarkable that no skeleton, or fragments thereof, or evidence of cremation, have been found. It has been suggested as possible that the burial mound may have been intended to confer the last rites on a leader whose body had been lost at sea. Should further relics accrue, presumably they will be added to the original gift, with a generosity worthy of the owner. The verdict of the Coroner's inquest, however, has given rise to some serious misgivings as to the possibilities to which a find of this value, and in such circum. stances, is exposed. It has been suggested that drastic measures should be taken by legislation to ensure their reservation to the nation. It is probable that any such action would defeat its own end. The generous interpretation of compensation now accepted in application of the law of treasure trove, which ensures to the finder the full archæological value of a find, and the vigilance of the Office of Works, are adequate to meet ordinary contingencies, while any exceptional find, such as that at Sutton $\mathrm{Hoo}$, is certain of the protection of a publicity which would be intolerant of anything in the nature of improper disposal.

\section{A Museum of the Roman Wall: An Appeal}

WHile some, at least, of the advantages of an adequate display for relics from the Roman Wall must be obvious to every layman who gives the matter a thought, only an archæologist can appreciate to the full both the hindrances to Romano-British studies of the present arrangements, as well as the benefits which would follow from the appropriate grouping of the collections in premises dedicated to this sole purpose. Mr. Ian A. Richmond, lecturer in RomanoBritish archeology in the University of Durham, in a review in The Times of August 29 of the present position, touches upon both aspects of the matter in putting forward a plea for better accommodation for at least some of the collections under the custody of the University of Durham. At present the relics from the Wall aro divided between three principal museums, the Blackgate at Newcastle-upon-Tyne, Tullie House at Carlisle, and Chesters on the Wrall itself. These museums are both overcrowded and illadapted to the requirements of modern display. In particular, the Blackgate, the medieval gateway of the Castle, is the most urgent problem. Once a debtors' prison, it is dark and gloomy, yet it contains the collections of the Society of Antiquaries of Newcastle-upon-Tyne, which now have been in existence for more than a century and aro the most important source of information on the Wall and its area.

So strongly did the needs of the situation and the claims of Hadrian's WVall as "one of the universally famous monuments of our island" appeal to the Standing Commission on Museums and Galleries that it was from this body that the suggestion came that the responsibility of a museum of the Roman Wall should devolve upon the University of Durham; and following upon an expression of willingness by the Council of the Society of Antiquaries to transfer the custody of its collections to the University, and an appeal to the public by Lord Eustaco Percy, as representing the University, for funds to erect such a museum, the University Grants Commission has generously made an offer of $£ 5,000$ towards the cost of the building, provided the balance of $£ 15,000$ required is raised within two years. Mr: Richmond goes on to point to a number of directions in which study of Romano-British culture is hampered through lack of adequate and appropriate display of the material.

\section{Gloucester Museum}

REFERENCE was mado recently in the columns of Nature (July 15, p. 91) to the origin of certain of the provincial museums as centres of intellectual and social exchango in days of less easy transport and communication. An example of a museum originating in this manner and of the function it is now able to fulfil in municipal life is afforded by the Public Museum of the City of Gloucester. This museum was founded in 1859 by members of the Gloucester Literary and Scientific Association (now dissolved) and the Cotteswold Naturalists Field Club. The collections wero housed originally in two rooms lent by Mr. Sydney Dobell, but were removed to the Art School in 1872, and finally transferred to their present home in the Price Memorial Hall in 1900, having been handed over to the Corporation by deed in 1896. A scheme of reorganization has been com. pleted recently and the occasion marked by tho issuo of a "Short Guide to the Collections", which includes, in addition to the collections in the Public Museum, those of the Folk Museum in Bishop Hooper's Lodgings, opened by Dr. R. E. Mortimer Wheeler in 1935. The Public Museum covers both natural science and archxology; and specimens aro available for detailed examination by students and research workers in a reference room set aside for the purpose. The archæological specimens are in the main of local derivation, and are arranged to illustrate the development of the material culture of early man in the local environment down to Saxon times. Historical relics later than the Norman Conquest are to be found in the Folk Museum, which illustrates 